\title{
School Leadership and Denominational Identity: The Case of Roman Catholic-Founded Schools in Uganda
}

\author{
Anthony Mugagga Muwagga ${ }^{1, *}$, Gyaviira Musoke Genza ${ }^{2}, \operatorname{Rex}$ Ssemulya ${ }^{3}$ \\ ${ }^{1}$ College of Education and External Studies, Makerere University, Kampala, Uganda \\ ${ }^{2}$ Faculty of Humanities, Uganda Martyrs University, Nkozi, Mpigi, Kampla, Uganda. \\ ${ }^{3}$ Uganda Martyrs Senior secondary School Namugongo Kampala Uganda \\ *Corresponding author: amugagga@educ.mak.ac.ug
}

Received August 07, 2013; Revised August 31, 2013; Accepted September 24, 2013

\begin{abstract}
This paper tries to answer the question: Do leaders in denominational founded schools practice faith based leadership? It attempts to give an explanation why the different stakeholders allege that school leadership is the prime cause for the diminishing presence of denominational identity in most these schools Uganda. The paper uses the Roman catholic founded schools as a case study. Subsequently, it discusses recommendations for reform, including the supposedly ideal qualities of a good 'faith' school leader. It calls for rejuvenation of denominational values in the management of schools founded and owned by the Church.
\end{abstract}

Keywords: school leadership, denominational, catholic identity and philosophy of education

Cite This Article: Anthony Mugagga Muwagga, Gyaviira Musoke Genza, and Rex Ssemulya, "School Leadership and Denominational Identity: The Case of Roman Catholic-Founded Schools in Uganda." American Journal of Educational Research 1, no. 8 (2013): 327-333. doi: 10.12691/education-1-8-10.

\section{Introduction}

School leadership and denominational identity are very important topics given the rampant abuse of office and the glaring corruption reminiscent of most of the civil servants and other leaders in private and public enterprises in Africa today, many of whom are graduates of the Church denominational Schools. It may be hard to rectify the seemingly bed ridden leadership without examining it from the educational enterprise/ school context as a ground for grooming of new leaders both in the spiritual and secular world. The educational enterprise is one of the oldest ventures of man and the leadership therein is also an old but complex domain to discuss. Leadership is carried out by man and for man but man is a complex being, who is both corporeal and spiritual and men are saliently different in terms of race, tribe, color, thoughts, values beliefs and tradition or culture. Unlike other beings like trees which grow on their own in the wild, man needs support in order to realize his/her full potential and also to fit in his/her society or community. Man grows and needs nurturing. The nurturing takes place both at home and in other areas such as the school, church and the community he/she resides in. The school or the educational enterprise is a multi dimensional venture. It provides knowledge to the learners, employment to the providers or custodians of knowledge and is of concern to many other education stakeholders. The key stakeholders are: parents, school administrators, academic and non academic staff, support staff, students and many other non explicit stakeholders for example the Church and Christ its anchor. For any success to be registered in an educational institution/enterprise all the above stake holders have to play their respective roles. For these roles to be successfully met there has to be coordination or leadership. In this paper the coordinators are supplied at the recommendation of the denominational body. In the Ugandan context denominational schools are faith based or founded on either Roman Catholic, Islamic, Anglican Church, Seventh day Adventist, orthodoxy or the Pentecostal Spiritual tradition. The paper singles out the Roman Catholic schools which pride in a well defined philosophy of education.

\section{Leadership}

Leadership is a process of influencing others to understand and agree about what needs to be done and how to do it, and the process of facilitating individuals and collective efforts to accomplish shared objectives [18,22] leadership refers to an influence relationship among leaders and followers who intend real changes that reflect their mutual purposes. These definitions imply exemplary leadership; they also imply that not only school administration is leaders; teachers and students too could be leaders. In the school context the definition of leadership implies: settings goals, objectives and strategies, motivating staff and students, allocation of resources (pedagogical and non pedagogical), designing of formal structures, programs and systems on which the school operates. In this paper we talk of school leadership in the Roman Catholic school context. In this context (faith based leadership) the prime role of school leadership as explained by [3] is the collaboration between the 
family/parents, teachers and school management to help nurture the young into responsible adults who are true to the mission of the Roman Catholic Church which emanates from Christ's command (in Mt 28: 18-26): which is "go, teach and make disciples of all nations." This command acts as the anchor on which all leadership in the catholic school context rotates. The lives and pedagogy of all school leadership has to be regulated by the example and life of Christ the Arch-priest and prototype head teacher.

\subsection{Catholic Identity, Philosophy and School Leadership}

A Catholic founded school is one canonically set up, authorized and recognized as such by the local ordinary of a given area of ecclesiastical jurisdiction [11]. Catholic founded schools pivot on an educational philosophy which dictates that a true Roman catholic founded school should be characterized by a holistic concern to develop the whole person, its attention to religious and moral education of learners through prayer, the Eucharist and other sacraments along with devotion [15] and teaching by example, especially the behavioral example of staff and cooperation with the local Ordinary through the Education Secretary, school chaplains and the parish priest [20]. It offers a formation that caters for both students' mundane and the final end [11]. Catholic education is therefore a convergence of faith and reason as [3] argues.

On the other hand in broad terms, "Catholic school leadership” refers the head teacher, deputies, class teachers, disciplinary committee heads, Board of Governors, school Management committee, Diocesan Education Secretaries, Parents and the student leaders [13]. The most important responsibility of catholic School leadership is their commitment to the mission and ethos of their schools, since they are the immediate custodians of the cultural heritage of such institutions. For this paper, however, "Catholic leadership" will specifically refer to the head teacher as the immediate custodian of the Roman Catholic tradition and identity in her/his area of jurisdiction. While "effective" implies being able to fulfill the goal, objectives and mission of Roman Catholic education as expressed in the Declaration on Christian Education [3]. The issue of Catholic school leadership and Catholic identity very important because the Catholic Church plays a salient role in the provision of education to a large section of the Ugandan population. In Uganda the Catholic Church runs 512 Kindergartens for 44807 infants, 33850 Primary Schools for 2249801 pupils, 559 Secondary schools for 208540 students and over 20 tertiary institutions excluding religious formation houses/seminaries [2].

\section{Methodology}

The study employed a cross- sectional sample survey design which was largely descriptive and qualitative in nature. The study population included the different education stakeholders in the greater Kampala Archdiocese. It specifically targeted 26 Catholic founded schools in Masaka diocese and 26 schools within the same paradigm in Kampala Archdiocese metropolitan. It examined respectively, 13 primary and 13 secondary schools in each respective diocese. The study sample was selected basing on [4] adapting the recommendations and sample determination table of Krejcie and Morgan, which reveals that beyond a certain point (about $\mathrm{N}=5000$ ), the population size is almost irrelevant and the sample of between 400 or 500 would suffice. In order to access the appropriate study sample, the study employed the convenient, simple random and purposive sampling techniques. The respondents are categorized into four groups namely.

- Category one: Teachers, head teachers and their deputies.

- Category two: Masaka Diocese and Kampala Archdiocesan Education officers, Parish Priests and School Chaplains/Fathers-in-charge.

- Category three: Students and Student Leadership.

- Category four: School Management Committee members (SMC) and Board of Governors (BOG) people in the school neighborhood.

Table 1. The target and actual study population

\begin{tabular}{|c|c|c|c|}
\hline \multirow[t]{2}{*}{ Sample Category \& study instrument used } & \multicolumn{2}{|c|}{ Number of respondents } & \multirow{2}{*}{$\begin{array}{c}\text { Percentage per overall Study Sample } \\
\%\end{array}$} \\
\hline & targeted & Actual & \\
\hline Head teachers/Deputies(Interview & 30 & 23 & 2.7 \\
\hline Class Teachers ( Questionnaires ) & 120 & 100 & 11.76 \\
\hline BOG \& Community ( interview guide) & 20 & 15 & 1.7 \\
\hline $\begin{array}{c}\text { Masaka, Kampala Metropolitan } \\
\text { Education Officers, Parish Priests\& Chaplains ( interview guide) }\end{array}$ & 60 & 53 & 6.23 \\
\hline Total & 850 & 640 & 75.21 \\
\hline
\end{tabular}

$\mathrm{N}=850$

Table 1 presents tabulations of study sample, targeted and actual study respondents. It reveals that out of the targeted 850 sample population, study was able to access 754 respondents (75.21\%).

\section{Study Findings}

The study findings are in response to the question: Does school leadership practice the Roman Catholic identity indicators. It is from the responses given by the different respondents that the study was able to decipher the challenges to Catholic identity in catholic founded Secondary and Primary schools in Masaka diocese and Kampala archdiocese were deciphered.

\subsection{Indicators of an Ideal Roman Catholic School Leadership}

There are many measures of effective leadership. However in the school context, it may be hard to convince people that one is an effective leader if the educational 
goal is not achieved. The educational goal on many occasions is measured using parameters outside the school and may not be very explicit. Some of the parameters used to measure effectiveness leadership are external examinations set by people outside the individual school and not in the control of the specific school leader; it also includes the implicit and explicit values depicted by the school products. In this paper the study identified some indicators of what is conceptualized to be effective leadership in a Roman Catholic School. These indicators are hereby conceptualized to include the following;

1. Prayerful and encourages others to pray in public and private.

2. Knows the Roman Catholic Philosophy of education and ethos.

3. Receives sacraments and regularly attends mass and other Roman catholic rites.

4. Respects him/herself and thus is respected by both the staff, the students and other school stakeholders and is able to make others under him/her grow in faith and love of neighbor.

5. Fosters godliness in the School and he/she is not ashamed to have/wear a sacramental in public.

6. Leadership style encourages team work and is ready to delegate to his/her juniors. That is he/she consults and usually seeks for consensus before taking a decision.

7. Practices servant leadership that is he/she is humble, empathic, listens, accepts corrections with no grudge, and does not abuse teachers in private or public, exercises stewardship of the Church school.

8. Does not abuse the school financial, human and physical resources.

9. Morally upright in terms of sexual conduct and other civic moral obligations of a professional educator such as being prudent, fair, assiduous, and impartial to all.
10. Lives a life of witnessing to Christ by example to the staff, students, parents and other relevant school stakeholders.

11. Loves his/her job and is willing to sacrifice personal time and resources on behalf of the school/students and teachers.

The different catholic education stake holders were requested to indicate whether the above indicators are practiced in their schools. The study findings are presented basing on each specific sample category.

\subsubsection{Category one Head Teachers/Deputies (H/D)\& Teachers (T)}

Findings in Table 2 reveal that 55\% of the head teachers noted that being prayerful and encouraging others to pray in public and private is not practiced by Roman Catholic school leadership. On the other hand $87 \%$ of the teachers also revealed that it is not practiced. Also 62\% of the head teachers revealed that receiving sacraments and regularly attending mass and other Roman Catholic rites are not practiced genuinely by school leadership. These findings were further elaborated by responses revealed in the interview sessions where one head teachers said:

"Receiving sacraments is a private issue between me and my God I don't see why they peg it to our performance. There many people who are not married legally, and so don't receive sacraments, and yet they perform better than the so-called legally married head teachers. (Response by one head teacher in one of the study schools June 2012).

While one teacher said:

"I am sure our head teacher and many of us go to church not because we are very convinced of it but because we need to protect our jobs (Allegation made by one teacher in one of the study schools in Kampala Archdiocese).

Table 2. Head Teachers/deputies \& Teachers' response to the question ( Do you think the following are practiced in your school?

\begin{tabular}{|c|c|c|c|c|}
\hline \multirow[t]{3}{*}{ Roman Catholic identity indicators } & \multicolumn{4}{|c|}{$\begin{array}{l}\text { Responses on the indicators of effective leadership in a Catholic Founded } \\
\text { School in terms of percentages deemed appropriate or not }\end{array}$} \\
\hline & \multicolumn{2}{|c|}{ Practiced } & \multicolumn{2}{|c|}{ Not Practiced } \\
\hline & $\mathrm{H} / \mathrm{D}$ & $\mathrm{T}$ & $\mathrm{H} / \mathrm{D}$ & $\mathrm{T}$ \\
\hline Prayerful and encourages others to pray in public and private & $45 \%$ & $13 \%$ & $55 \%$ & $87 \%$ \\
\hline Knows the Roman Catholic Philosophy of education and ethos & $47 \%$ & $56 \%$ & $53 \%$ & $44 \%$ \\
\hline $\begin{array}{l}\text { Receive sacraments and regularly attend mass and other Roman catholic } \\
\text { rites }\end{array}$ & $38 \%$ & $48 \%$ & $62 \%$ & $52 \%$ \\
\hline $\begin{array}{l}\text { Respects him/herself and thus is Respected by both the staff, the students } \\
\text { and other school stakeholders and is able to make others under him/her } \\
\text { grow in faith and love of neighbor. }\end{array}$ & $100 \%$ & \multicolumn{2}{|c|}{$100 \%$} & \\
\hline $\begin{array}{l}\text { Fosters godliness in the School. He/She is not ashamed to have/wear a } \\
\text { sacramental in public }\end{array}$ & $65 \%$ & \multicolumn{2}{|c|}{$100 \% 35 \%$} & \\
\hline $\begin{array}{l}\text { Leadership style encourages team work and is ready to delegate to his/her } \\
\text { juniors }\end{array}$ & $75 \%$ & $35 \%$ & $25 \%$ & $65 \%$ \\
\hline $\begin{array}{l}\text { Practices servant leadership: humble, empathic, listens, accepts corrections } \\
\text { with no grudge, does not abuse teachers in private or public, exercises } \\
\text { stewardship of the Church school }\end{array}$ & $92 \%$ & $34 \%$ & $8 \%$ & $66 \%$ \\
\hline Does not abuse the school financial, human and physical resources & $40 \%$ & $43 \%$ & $60 \%$ & $57 \%$ \\
\hline $\begin{array}{l}\text { Morally up right in terms of sexual conduct and other civic moral } \\
\text { obligations of a professional educator such as prudent, fair, assiduous, } \\
\text { impartial to all }\end{array}$ & $43 \%$ & $39 \%$ & $57 \%$ & $61 \%$ \\
\hline Lives a life of witnessing to Christ & $38 \%$ & $23 \%$ & $62 \%$ & $77 \%$ \\
\hline $\begin{array}{l}\text { Loves his job and is willing to sacrifice personal time and resources on } \\
\text { behalf of the school/students and teachers. }\end{array}$ & $56 \%$ & $29 \%$ & $44 \%$ & $71 \%$ \\
\hline
\end{tabular}

$\mathrm{N}=123$ (Head Teachers/Deputies=23 \& Teachers=100)

The most striking finding in Table 2 , is the fact that $92 \%$ of the head teachers did accept that they practice faith based leadership as a prime leadership model of
Catholic School leadership but in contrast to them $66 \%$ of the teachers said it is not practiced. The explanation to this is found in the views head teachers expressed which 
suggested that head teachers seem to be more lax in their attitude, approach and interpretation of faith based leadership and catholic identity vis avis their duty and leadership obligations. On the other hand, the teachers seem to be more conservative and rigid in as far as catholic identity, ethos and philosophy are concerned as evidenced in study findings in Table 2 . They expect much from the head teachers as the prime custodians of both the secular and denominational order in the school and when they see the opposite challenges come in.

4.1.2. Category two: Masaka Diocese and Kampala Archdiocesan Education officers (E), Parish Priests (PP) and School Chaplains (SC)/Fathers-in-charge (FIC)

Table 3. Masaka Diocese and Kampala Archdiocesan Education officers (E), Parish Priests (PP) and School Chaplains (SC)/Fathers-in-charge (FIC) response to the question (Do you think the following are practiced in your school?)

\begin{tabular}{|c|c|c|c|c|c|c|}
\hline \multirow[t]{3}{*}{ Roman Catholic identity indicators } & \multicolumn{6}{|c|}{$\begin{array}{l}\text { Responses on the indicators of effective leadership in a Catholic Founded } \\
\text { School in terms of percentages deemed practiced or not }\end{array}$} \\
\hline & \multicolumn{3}{|c|}{ Practiced } & \multicolumn{3}{|c|}{ Not Practiced } \\
\hline & $\mathrm{E}$ & PP & SC & $\mathrm{E}$ & PP & $\mathrm{SC} / \mathrm{FIC}$ \\
\hline Prayerful and encourages others to pray in public and private & - & - & $56 \%$ & & & $44 \%$ \\
\hline Knows the Roman Catholic Philosophy of education and ethos & $100 \%$ & $100 \%$ & $100 \%$ & & & \\
\hline $\begin{array}{l}\text { Receive sacraments and regularly attend mass and other Roman } \\
\text { catholic rites }\end{array}$ & $100 \%$ & $100 \%)$ & $79 \%$ & & & $21 \%$ \\
\hline $\begin{array}{l}\text { Respects him/herself and thus is Respected by both the staff, the } \\
\text { students and other school stakeholders and is able to make others } \\
\text { under him/her grow in faith and love of neighbor. }\end{array}$ & $100 \%$ & $100 \%$ & $100 \%$ & & & \\
\hline $\begin{array}{l}\text { Fosters godliness in the School. He/She is not ashamed to have/wear a } \\
\text { sacramental in public }\end{array}$ & $100 \%$ & $100 \%$ & $100 \%$ & & & \\
\hline $\begin{array}{l}\text { Leadership style encourages team work and is ready to delegate to } \\
\text { his/her juniors }\end{array}$ & $100 \%$ & $100 \%$ & $100 \%$ & & & \\
\hline $\begin{array}{l}\text { Practices servant leadership : humble, empathic, listens, accepts } \\
\text { corrections with no grudge, does not abuse teachers in private or } \\
\text { public, exercises stewardship of the Church school }\end{array}$ & $89 \%$ & $72 \%$ & $66 \%$ & $11 \%$ & $28 \%$ & $34 \%$ \\
\hline Does not abuse the school financial, human and physical resources & $48 \%$ & $49 \%$ & $32 \%$ & $52 \%$ & $49.9 \%$ & \\
\hline $\begin{array}{l}\text { Morally up right in terms of sexual conduct and other civic moral } \\
\text { obligations of a professional educator such as prudent, fair, assiduous, } \\
\text { impartial to all }\end{array}$ & $100 \%$ & $100 \%$ & $100 \%$ & & & \\
\hline Lives a life of witnessing to Christ & $82 \%$ & $72 \%$ & $61 \%$ & $18 \%$ & $28 \%$ & $39 \%$ \\
\hline $\begin{array}{l}\text { Loves his job and is willing to sacrifice personal time and resources } \\
\text { on behalf of the school/students and teachers. }\end{array}$ & $67 \%$ & $77 \%$ & $78 \%$ & $33 \%$ & $23 \%$ & $22 \%$ \\
\hline
\end{tabular}

$\mathrm{N}=60(\mathrm{E}=17, \mathrm{PP}=18, \mathrm{SC}=/ \mathrm{FC}+18)$

Findings in Table 3 reveal that the Masaka Diocese and Kampala Archdiocesan Education officers (E) Parish Priests (PP) take the issues of regularly attending mass and other Roman Catholic rites, witnessing to Christ and servant leadership as important and practiced in the respective study schools. Though some few noted that they could not give conclusive answers since they do not stay at school all the time but noted that some of these things are personal but an obligation for all the baptized. Many of these clerics were not in position to divulge more on the issue of sacraments, witnessing to Christ and moral uprightness due to their secrecy vows and other theological and spiritual obligations and imperatives. The only significant response was from one School Chaplain who said:

"The head teacher in my area of jurisdiction attends mass every day, receives sacraments and pretends to be a holy man but he is a thief, a liar and he is known for domestic violence and is very untrustworthy. Yet and yet I know one head mistress who is not legally married, but apart from that she is a real commendable Roman Catholic in word and deed"( Response by one School Chaplain in one of the study schools).

While an officer from the diocesan education secretariat on the issue of witnessing to Christ said:

"Many of the so called BOG are on the School Boards not to pursue or monitor the implementation and permeation of the school environment with Catholic identity but to ease and facilitate their friends the head teachers to plunder our schools. I don't think this is what we should call witnessing to Christ in a Roman Catholic School" (A view expressed by one priest working at the education secretariat in one of the study dioceses in an interview session).

The above findings seem to suggest that the immediate representatives of the different Ordinaries where the schools are located are comfortable with the school leadership and their effectiveness in the maintenance of the Catholic identity in the respective Roman Catholic schools. It may be very hard to conclusively read the mind and implications of the cleric's responses but one cannot fail to smell a rat in as far as some clerics abrogating their obligations and duty of school inspection and monitoring as dictated by Roman catholic Canon 803, par. 1, dictates that by virtue of the position and role of a catholic school the priest therein plays a very important place and role.

\subsubsection{Category three: Students (S) and Student Leadership ( SL)}

The study also sought to establish whether according to students the listed Roman Catholic school indicators of an effective leadership are practiced in their respective schools. Findings from the students and student leadership responses are presented in Table 4. 
Table 4. Students (S) and Student Leadership ( SL) response to the question (Do you think the following are practiced by the leadership in your school?

\begin{tabular}{|c|c|c|c|c|}
\hline \multirow[t]{3}{*}{ Roman Catholic identity indicators } & \multicolumn{4}{|c|}{$\begin{array}{l}\text { Responses on the indicators of effective leadership in a Catholic } \\
\text { Founded School in terms of percentages deemed practiced or not }\end{array}$} \\
\hline & \multicolumn{2}{|c|}{ Practiced } & \multicolumn{2}{|c|}{ Not Practiced } \\
\hline & $\mathrm{S}$ & SL & $\mathrm{S}$ & SL \\
\hline Prayerful and encourages others to pray in public and private & $100 \%$ & $100 \%)$ & & \\
\hline Knows the Roman Catholic Philosophy of education and ethos & - & - & & \\
\hline Receive sacraments and regularly attend mass and other Roman catholic rites & $100 \%$ & $100 \%$ & & \\
\hline $\begin{array}{l}\text { Respects him/herself and thus is Respected by both the staff, the students and } \\
\text { other school stakeholders and is able to make others under him/her grow in } \\
\text { faith and love of neighbor. }\end{array}$ & $(100 \%)$ & $100 \%)$ & & \\
\hline $\begin{array}{l}\text { Fosters godliness in the School. He/She is not ashamed to have/wear a } \\
\text { sacramental in public }\end{array}$ & $100 \%$ & $100 \%$ & & \\
\hline $\begin{array}{l}\text { Leadership style encourages team work and is ready to delegate to his/her } \\
\text { juniors }\end{array}$ & $100 \%$ & $100 \%$ & & \\
\hline $\begin{array}{l}\text { Practices servant leadership : humble, empathic, listens, accepts corrections } \\
\text { with no grudge, does not abuse teachers in private or public, exercises } \\
\text { stewardship of the Church school }\end{array}$ & $38 \%$ & $40 \%$ & $62 \%$ & \\
\hline Does not abuse the school financial, human and physical resources & $53 \%$ & $65 \%$ & $47 \%$ & \\
\hline $\begin{array}{l}\text { Morally up right in terms of sexual conduct and other civic moral obligations } \\
\text { of a professional educator such as prudent, fair, assiduous, impartial to all }\end{array}$ & $100 \%$ & $100 \%$ & & \\
\hline Lives a life of witnessing to Christ & $55 \%$ & $65 \%$ & $45 \%$ & \\
\hline $\begin{array}{l}\text { Loves his job and is willing to sacrifice personal time and resources on behalf } \\
\text { of the school/students and teachers. }\end{array}$ & $100 \%$ & $100 \%)$ & & \\
\hline
\end{tabular}

of the school/students and teachers.

$\mathrm{N}=449$ (SL=89 \& $\mathrm{S}=360)$

Findings in Table 4 reveal that students seem to accept that the indicators of Roman Catholic Identity and ethos are practiced by school leadership. This therefore impacts on their interpretation of Catholic identity and witnessing to Christ. The findings also reveal that a salient student leadership percentage $89 \%$ seem to agree that their school leadership are playing their true role of enhancing catholic identity. The only key issue raised by students was on abuse of school financial, human and physical resources. This they felt could in the long run constrain true witnessing to Christ. To this one student leader noted and said:

"Many of the head teachers force our parents to bring a lot of un necessary requirements for example toilet papers reams of paper, hoes and yet we do not dig, brooms, soap and at times books. We are not sure if these are all used here in the school" (Response from an open ended question in a student leader's questionnaire).

While another student leader also noted that said:

"Our parents pay a lot of money but we are fed badly, this is an abuse and not a good witnessing to Christ" (Response got from a student's open ended questionnaire question).

The above findings imply that though many of the students seem to be young in age they know what ought to be a good leader in a true Roman Catholic School. The responses by the students cut across the school level divide both the primary and secondary school students' leaders gave similar responses.

Table 5. Members of BOG and the Community neighboring the school response to the question (Do you think the following are practiced by the school leadership in your Catholic School?)

\begin{tabular}{|c|c|c|c|c|}
\hline \multirow[t]{3}{*}{ Roman Catholic identity indicators } & \multicolumn{4}{|c|}{$\begin{array}{l}\text { Responses on the indicators of effective leadership in a Catholic } \\
\text { Founded School in terms of percentages deemed practiced or not }\end{array}$} \\
\hline & \multicolumn{2}{|c|}{ Practiced } & \multicolumn{2}{|c|}{ Not Practiced } \\
\hline & BOG/SMC & $\mathrm{C}$ & BOG/SMC & $\mathrm{C}$ \\
\hline Prayerful and encourages others to pray in public and private & $100 \%$ & $100 \%$ & & \\
\hline Knows the Roman Catholic Philosophy of education and ethos & $100 \%$ & - & & \\
\hline Receive sacraments and regularly attend mass and other Roman catholic rites & $100 \%$ & $100 \%$ & & \\
\hline $\begin{array}{l}\text { Respects him/herself and thus is Respected by both the staff, the students and } \\
\text { other school stakeholders and is able to make others under him/her grow in faith } \\
\text { and love of neighbor. }\end{array}$ & $100 \%$ & $100 \%$ & & \\
\hline $\begin{array}{l}\text { Fosters godliness in the School. He/She is not ashamed to have/wear a } \\
\text { sacramental in public }\end{array}$ & $100 \%$ & $100 \%$ & & \\
\hline Leadership style encourages team work and is ready to delegate to his/her juniors & $68 \%$ & $70 \%$ & $32 \%$ & $30 \%$ \\
\hline $\begin{array}{l}\text { Practices servant leadership : humble, empathic, listens, accepts corrections with } \\
\text { no grudge, does not abuse teachers in private or public, exercises stewardship of } \\
\text { the Church school }\end{array}$ & $68 \%$ & $60 \%$ & $32 \%$ & $40 \%$ \\
\hline Does not abuse the school financial, human and physical resources & $40 \%$ & & & \\
\hline $\begin{array}{l}\text { Morally up right in terms of sexual conduct and other civic moral obligations of } \\
\text { a professional educator such as prudent, fair, assiduous, impartial to all }\end{array}$ & $100 \%$ & $100 \%$ & & \\
\hline Lives a life of witnessing to Christ & $68 \%$ & $40 \%$ & $32 \%$ & $60 \%$ \\
\hline $\begin{array}{l}\text { Loves his job and is willing to sacrifice personal time and resources on behalf of } \\
\text { the school/students and teachers. }\end{array}$ & $100 \%$ & $100 \%$ & & \\
\hline
\end{tabular}

$\mathrm{N}=30$ (BOG/SMC $=10 \& \mathrm{C}=5)$ 


\subsubsection{Category four: Members of BOG and the Community Neighboring the School}

On the other hand the Members of the Board of Governors and the community neighboring the study schools revealed the following as indicated in Table 5.

Findings in Table 5 seem to concur with study categories 1, 2 \& 3 who reveal that most of the basic indicators are practiced by school Leadership apart from $40 \%$ of the BOG and $60 \%$ of the community respondents who were not very comfortable with how school leadership is witnessing to Christ and practicing of servant leadership while 32 of BOG and $40 \%$ of the Community members were not comfortable with the Leadership style of the school leadership. The above quantitative findings were enhanced by qualitative responses from in which it was revealed that there cases of school leadership indiscipline. They for example one said:

"I think those people who all the time carry the holy rosary are deceiving the public. If they were good Catholics then their behavior would also reflect what they wear. But many of them are liars, sell students scholastic and other non scholastic items to us in the village, but of course they have to impress the priests" (An Allegation made by one Community member).

While another respondent said:

"Many of the board members are friends of the head teacher how can they properly supervise them. They on at times collude with them to steal and abuse school property" (Allegation made by one School Chaplain in an interview session).

One BOG member said:

"All head teachers know the Roman catholic Philosophy of education and ethos since all of them are interviewed and they pass and these are some of the questions. They only pretend not to know what to do or do it badly but they know it and they try their best but remember they have to run our schools while competing with the secular schools because these schools are not seminaries or novitiate"(Response from a discussion with one BOG member in one of the study schools 2012).

While another SMC member quoting the [6], he revealed:

"We have many absent school head teachers many of whom never keep at school they are more in their personal businesses, while their deputies do the actual school administration".

The above findings imply that it may not be out of ignorance of the Roman Catholic school mission and philosophy by the school leaders that we have a failed catholic identity. There are other explicit and implicit factors other than ignorance. These factors might be anchored in current secularized or commercialized school system in Uganda. Some of which include: people who are not well grounded in their faith and commitment to Christ and the church, complacency, ethical relativism and the vacuum of role models both in the secular and spiritual arenas.

\section{Reflections and the Way Forward}

In the absence of good role models at home, in the church and in the community, the school remains the "ideal" teacher or centre for knowledge birth and edification. For the school to play its role, there must be implicit and explicit factors on which the school pedagogy. Salient among these is the school leadership. Like earlier studies on catholic education and school leadership in sub Saharan Africa and elsewhere, $[5,16]$ the study makes explicit and implicit revelations on what ought to be the conduct and role of a leader in the Roman Catholic school 'ipso facto' a denominational school. Though some respondents seemed uncomfortable with some indicators they did not deem them useless or inappropriate but rather many noted that they are absent in the day today practice of most catholic school leadership. This seems to concur with $[12,13,17]$, who all note that there are many well set good practices for all Roman Catholic Schools but they are annihilated intentionally or unintentionally because of greed, poor supervision by the Ordinary or out of sheer ignorance of what is to be done in these schools. Many catholic school stakeholders seem not to be well tutored in the Catholic school tradition and school philosophy. In order to overcome this anomaly the Church to fulfill her mandate and obligation to transmit both the tradition and faith as given [2b], it needs a leadership which is not only well tutored in Catholic philosophy of education but which is also committed and has been nurtured in the catholic identity and the "Magisterium" or the teaching authority of the Catholic Church.. It is this good leadership as noted in the Declaration on Christian education [3] which will enable the modern Children to become more aware of the gift of faith they received at baptism and thus will come to appreciate other sacraments. This may help overcome the challenge the church in Europe seems to be facing already. A challenge predicted by Friedrich Nietzsche when he noted that the death of God led to the death of European morality with dare consequences such as glorifying pornography and the ill of ethical relativism espoused by the so-called civilized gentleman and woman.

The current catholic school leadership challenges seem to have emanated from the Uganda Post Independence secularization of denominational education when government in 1963 using the Amended Education Act 1963 which basing on the arguments of the minister of education then argues that: "the church should seek to find its strength from the pulpits and let the state concentrate on the school system" [6] By 1964 this amended education Act terminated the age long commanding position of the churches in education in terms of planning, financing, evaluation and administration, all of which were passed on to the state [16]. Secularization of education became the death bed of denominational identity in most schools in Uganda. The challenges were further aggravated by the political and economic problems Uganda faced in its infancy post independence years in the 1970s and 1980s.During these years many elites left the country, many teachers abandoned teaching to do petty trade as a result school enrolment declined drastically $[7,14]$. The constrained leadership in the country as noted by [21], the light of the world calls on all leaders in Uganda to act as the light for those they lead so that by their good works others will get to know God (Mt 5; 1314) In the school context education is like a sign post which leads to some destiny hence school leadership has to act as signpost for all students to realize their destiny. 
In order to rekindle the Catholic tradition identity in the Roman Catholic founded schools: Today the Roman Catholic School leadership has to have the following characteristics or possess the following qualities;

- They have to be men and women of prayer or people whose words and actions speak loud, their conduct in deed and word should be a good example to the learners and staff. Their private, public life and actions must reflect that of the Master (Jesus), they should be men and women who are able to help others grow in faith, love of God and neighbor, they have to be men and women who do not trust their own but the might of the lord and whatever they do should be done for the greater glory of God "Ad magnum Gloriam dei” which is the Jesuit education and motto.

- In disciplining children there is an imperative to cultivate in them a sense of duty and help inculcate in them the awareness of their dual nature and destiny. That is in as much as they have to pass the earthly examinations they have to remember that these all are a means to a greater end which is eternal life. To do this there is need to orient all those aspiring to head Catholic schools into the Roman Catholic school tradition and catholic philosophy of education.

- The head teacher is the first teacher of Catholic moral education ( Catholic Moral education Syllabus ) $\mathrm{He} / \mathrm{she}$ must be able without cowardice to talk and dissuade both the teachers and students from things which the church abhors for example homosexuality, drug abuse and other contemporary vices which demean the human and Christ's image in us.

- At all times the head teacher should be able to provide both secular and pastoral counseling to all stakeholders of his/her school. Since, in the absence of the school catholic Chaplain and other authentic ordained ministers, he/she becomes the first pastor to reach them. In most cases education stakeholders face a number of challenges which if not handled well mortify the sought education, challenges such as domestic violence, child abuse, marital challenges and outright atheism head teachers have to come in hand to provide counseling where possible.

- Head teachers have the moral and spiritual obligation both as professional teachers and baptized Christians to carry out their catechetical duty in their area of jurisdiction which is the school.

- Though it is agreed that sacraments are at times a private issue between the recipient and his/her God, school leadership given their position have to have knowledge of the different sacraments namely: baptism, penance, Eucharist, confirmation, holy matrimony, holy orders and anointing of the sick. These are essential for the life of a Catholic because they were instituted to be a bearing or anchor on which lives of Christ's followers pivot on. Catholic school leadership should practice them and base on them to follow the examples of Christ the arch teacher.
- The head teachers should always follow the example of Christ who told his disciples to serve and not be served: "Non ministrari, sed ministrare" This is drawn from the example of Christ who came to serve and not to be served, giving a practical example to all leaders to emulate by washing his disciples feet. ( Jn 13: 1-17).

\section{References}

[1] Archdiocese of Kampala, A Catholic's Mission in the Arch Diocese of Kampala, Marianum Press Ltd. Kampala, 2006, 10-30.

[2] Agenzia Fides Catholic Church year book statistics 2012, http://www.fides.org/en/news/30147Vatican [accessed on Aug.5, 2012].

[3] Flannery,A.,Ed, Declaration on Christian Education. Vatican Council II Post Councilor Documents Second edition Dublin: Dominican Press,1992,642-662.

[4] Gay, L.R., Educational Research competencies for Analysis and Application $5^{\text {th }}$ edition, Merrill New Jersey, 1996, 124

[5] Giusaani, L., The Risk of Education. Discovering our ultimate destiny The Crossroad publishing company, New York, 2001.

[6] Hansard, Uganda Parliamentary Debates, National Assembly Official Report, $2^{\text {nd }}$ session of the First Parliament of Uganda, Part 4 of the $2^{\text {nd }}$ Meeting, $10^{\text {th }}$ December, 1963, vol.22, pp.536-54.

[7] Hansen B. H., Twaddle M. (Eds),Uganda Now between Decay and Development. East African Studies Heinemann, Nairobi 1991

[8] Herzberg, F. et al (1959). The motivation to work. New York. John Willey and sons.

[9] Herzberg F. (1969). "One more time" How do you motivate employees.” Harvard Business Review January- February.

[10] Hoy,W.K.,Miskel,C.G. (1987). Education Administration, Theory, Research and Practice. MacGraw Hill company, New York.

[11] John, P. II,The Code of Canon law. Collins Publications, Bangalore, 1983,145 (Code of Canon law, Canon 800 par.1).

[12] Kasasa. H. (2011). Teacher Remuneration and Teacher Performance in Catholic Privately owned Schools in Kampala Archdiocese. Un published MED Dissertation Makerere University.

[13] Kibuuka P, Human Resource Development and Management in Education. Un published Lecture notes, Makerere University, Kampala,2007, 23.

[14] Mamdani, M.( Politics and Class Formation in Uganda. Fountain Publishers, Kampala,1990.

[15] McCluskey,G. N.,Catholic View point on Education, Image Books, New York, 1962). 73-75.

[16] Munakukaama N. J Secularization of Post Independence Education in Uganda and its Significance for Moral Education in Public Primary and Secondary Schools. Un published Doctoral thesis Makerere University,Kampala 1997.

[17] Nabukenya, M. Influence of Teacher's Professionalism on Teacher Performance in Busir County Secondary Schools, Wakiso District. Un published MED desertion Makerere University Kampala, 2010.

[18] Rost, J. C. Leadership for the twenty-first Century,Praeger, London, 1993.

[19] Ssekamwa, J.C., A History and Development of Education in Uganda, Fountain Publishers,Kampala, 1997.

[20] Peticlerc, J. M. The Catholic School in Mission, Pontifical Missionary Union Rome, 2002,13-14.

[21] Wamala, E. You are the Salt of the earth, the light of the world.A Pastoral letter of His Eminence Emmanuel Cardinal Wamala. Archbishop of Kampala Archdiocese, 2001.

[22] Yukl, G. Leadership in Organizations. Pearson, New York, 2010, 26. 